\title{
Chapter 9 \\ Explaining Cross-National Differences \\ in Social Background Effects: What Have \\ We Learned?
}

\author{
Aart C. Liefbroer
}

\subsection{Introduction}

Demographic choices in young adulthood are socially stratified (Billari et al. 2019). These choices vary significantly by one's family of origin. As studies in numerous different countries have shown, young adults from poor socio-economic backgrounds (usually called 'low SES' from now on) start their family formation process earlier than young adults from better socio-economic backgrounds (Amato et al. 2008; Hobcraft and Kiernan 2001). But other aspects of one's family of origin have also been found to be associated with family formation processes. Young adults who were raised in households without one or both of their biological parents have been found to be more likely to start family formation earlier than young adults who were raised by both biological parents (Feldhaus and Heintz-Martin 2015). In addition, they are more likely to dissolve partner relationships they have entered (Wolfinger 2000). Thus, aspects of childhood disadvantage are clearly related to demographic outcomes.

Little is known, though, about whether the consequences of childhood disadvantage for demographic choices vary across countries, Although the number of cross-national studies examining family formation processes has increased dramatically in the last decades (Kalmijn 2007; Sobotka 2008; Van Bavel 2010), the vast majority of these studies has examined cross-national differences in the occurrence or the timing of specific family formation events (Billari and Liefbroer

\footnotetext{
A. C. Liefbroer $(\square)$

Netherlands Interdisciplinary Demographic Institute (NIDI), The Hague, The Netherlands

Department of Epidemiology, University Medical Centre Groningen, University of Groningen, Groningen, The Netherlands

Department of Sociology, Vrije Universiteit, Amsterdam, The Netherlands e-mail: liefbroer@nidi.nl
} 
2010). However, the number of studies that have examined cross-national differences in the correlates of the family formation process is much less extensive. Interesting examples of such studies are studies by Perelli-Harris and her collaborators on differences in the educational gradient of family formation processes across Europe (Perelli-Harris et al. 2010; Perelli-Harris and Lyons-Amos 2016), and studies on cross-national differences in the determinants of parental divorce (Härkönen and Dronkers 2006; Wagner and Weiß 2006). These studies have shown that considerable variation in the strength of the association between social characteristics and family formation processes often exist. As countries vary considerably in their economic, cultural and institutional conditions, it is likely that cross-national variation exists as well in the consequences of childhood disadvantage for demographic outcomes in young adulthood and for socio-economic and emotional well-being later on in the life course. However, this cross-national variation has hardly been studied till date.

In this Chapter, I will discuss some of the key issues involved in studying crossnational differences in social background effects on family formation. First, I will discuss some of the central theoretical ideas that can be used to derive hypotheses about the strength of these cross-national differences. Next, I will discuss the practical challenges facing scholars who want to study these cross-national differences. Subsequently, I present the main findings from the Contexts of Opportunity (CONOPP) project on which this book is based. I close by drawing some main conclusions and providing suggestions for future research.

\subsection{Theoretical Explanations for Cross-National Differences in Family Background Effects}

In a seminal article, Van de Kaa (1996) introduced the notion of 'anchored' narratives to synthesize the main storylines in research on the determinants of fertility. An anchored narrative is a good story that knits together a body of evidence. In that sense, there seem to be three types of narratives that could be used to explain (or predict) cross-national differences in the relationship between family background and family formation processes. These narratives are grounded either in cultural, economic or institutional understandings of the drivers of cross-national differences.

Fittingly, the cultural narrative most conducive to discussing cross-national differences in the relationship between family background and family formation processes, is Van de Kaa's and Lesthaeghe's Second Demographic Transition (SDT) narrative (Lesthaeghe and Van de Kaa 1986; Van de Kaa 1987; Lesthaeghe 2014). The SDT asserts that cultural changes in the Western world since the second World War, in particular trends towards increasing secularization and individualization, have made young adults more autonomous in their life choices, leading them to opt for demographic choices that allow for more autonomy (such as living independently or in a cohabiting union rather than a marriage) and to postpone demographic 
choices that ask for much commitment (Studer et al. 2018). The SDT theory clearly focuses on historical change, leading to changing behaviors within societies, but as these changes start at different time-points in different societies and also diffuse across societies at different speeds, it will also lead to large differences across societies in the family formation processes that are observed. Still, the SDT is more concerned in explaining differences between societies in family formation patterns itself than in cross-societal differences in the relationship between family background and family formation patterns. However, it is rather straightforward to derive implications for the strength of family background effects from the SDT. Processes of secularization and individualization will lead to young people being less susceptible to the normative instructions of key socializing agents like the Church, but also parents (Dobbelaere 1981; Gorski and Altinordu 2008). In addition, in an individualized society, parents themselves may be less willing to pressure their children into conforming to traditional ideas about family formation. As a result, it can be expected that family background will matter less to the family formation choices of young adults in societies in which the SDT has been diffused broadly than in societies that are more traditional.

Economic narratives constitute a second class of 'good stories' about crossnational differences in the association between family background and family formation patterns. In general, such narratives argue that societies with better economic prospects for young adults offer them better conditions to make their own decisions than societies where young adults face worse economic prospects. In these latter societies, young adults will presumably have to rely on the financial resources provided by their parents to a much larger degree. As a result, the family formation choices of young adults may mirror the often more traditional preferences of their parents to a larger extent than in economically better developed societies. Examples of such narratives are Perelli-Harris' idea of the Pattern of Disadvantage, that suggests that in less affluent Western countries decisions to cohabit unmarried and to have children outside marriage are less based on individualized preferences but on the lack of financial means to marry (Perelli-Harris and Gerber 2011) and Blossfeld's globalization theory that suggests that young adults postpone family formation and opt for less committal family types as a result of economic insecurity (Blossfeld et al. 2005).

Institutional narratives are a third class of 'good stories' that can be used to derive hypotheses about cross-national differences in the relationship between family background and family formation patterns (Thévenon and Gauthier 2011). The best-known institutional narrative is Esping-Andersen's theory about multiple worlds of welfare (Esping-Andersen 1990, 1999). Here the key idea is that countries differ in the kind of welfare arrangements that they have in place. Some of these arrangements are more supportive to disadvantaged families than others, and countries may also differ in the generosity of their support to young adults. Both of these factors can potentially influence differences in the strength of the association between family background and adult outcomes as welfare states can act as a buffer to the potentially detrimental consequences of childhood disadvantage. 
The introductory chapter of this book (Chap. 1) discusses that the basic premise of the CONOPP project is that demographic choice in young adulthood is not so much about individual choice as about unequal choice. In other words, demographic choices - and their consequences - are stratified. At the same time, the guiding hypothesis on Contexts of Opportunity is that the extent of inequality depends on the opportunities that societies offer to buffer the negative consequences of childhood disadvantage. In line with the three narratives outlined above, these opportunities can be cultural, economic or institutional in nature.

\subsection{Methodological Challenges in Testing the Contexts of Opportunity Hypothesis}

The theoretical approaches discussed in the previous section suggest that the strength of the relationship between social background, young-adult demographic behaviors and later-life outcomes depends on country-specific economic, cultural and institutional conditions. In testing these kinds of hypotheses, researchers are faced with four types of challenges.

A first challenge is to find cross-national micro-datasets that can be used to test hypotheses about differences in the consequences of childhood disadvantage. Basically, researchers have two options. They can either use national datasets that are not collected for comparative purposes, such as national socio-economic household panel surveys, or datasets from programmes that specifically have been developed to generate comparative data (Wolf et al. 2016). The first approach has the large drawback that questions that are used to measure the central concepts to be used in testing hypotheses have not been harmonized before the data are collected. As a result, post-harmonization of these measures is necessary to assure that data are comparable. This often is either impossible because questions are too incomparable to find any common denominator, or leads to a large reduction in the quality of measuring instruments. This problem is already present if data from two different countries are post-harmonized, but is even further exacerbated if data from more countries are needed. The only programmes having any level of success with this approach are programmes to harmonize socio-economic panel surveys (Frick et al. 2007) or to use register data from countries with high-quality register information (Ruggles 2014). However, more than a relatively small number of countries cannot be successfully compared using this approach. The second approach holds much more promise for comparative research. The key element is that questionnaires are a priori harmonized, strongly strengthening the international comparability of measurement instruments. The most important programmes of this kind with data on European countries are the European Social Survey (ESS) (Schnaudt et al. 2014), the European Values Study - EVS (Gelissen and Halman 2018), the Survey of Health and Retirement in Europe (SHARE) (Börsch-Supan et al. 2013) and the Generations and Gender Programme (GGP) (Gauthier et al. 2018). The ESS and 
EVS are repeated cross-sectional surveys. The ESS is conducted every 2 years, the EVS every decade. SHARE and GGP are panel surveys, conducted with an interval of two (SHARE) or three (GGP) years. The bulk of European comparative research is being conducted with data from one of these four surveys.

A second challenge to test comparative hypotheses about the role of childhood disadvantage is to find good indicators for both dependent and independent variables. Childhood disadvantage is a multidimensional concept. As a consequence, one would like to use multiple indicators, like for parents' socio-economic status e.g. parental education, parental occupation, parental income - and for family structure - e.g. the timing and type of changes in family structures across childhood. It turns out that no survey programmes have good indicators for all relevant aspects of childhood disadvantage, and that different survey programmes include different types of childhood indicators. The ESS, for instance has information on both parents' educational attainment and their occupational class, but not on childhood family structure. The GGP has information on parental education and on family structure at age 15, but not on parental occupations. SHARE has the most complete set of information, albeit only in its SHARELIFE module, but has the drawback that it focusses on people aged 55 and over and thus excludes relatively young cohorts. Selecting dependent variables of interest also pose a challenge. The best types of indicators for demographic decision-making during young adulthood are based on data about the month and year in which important life events, such as leaving home, union formation and childbirth, occurred. EVS, ESS and SHARE do not routinely include that kind of information. Only the GGP routinely includes rich information on the demographic life course. Fortunately, the LIFETIMING module included in the ESS rounds 3 and 9 and the SHARELIFE module incorporated in SHARE do have information on the year in which important demographic events occurred as well, resulting in a somewhat broader set of options to test key hypotheses on the relationship between childhood disadvantage and adult outcomes.

A third challenge is to find good indicators for national-level indicators to explain cross-national differences in the strength of the relationship between childhood disadvantage and adult outcomes. Here problems arise both with respect to the set of countries for which indicators have to be available and with respect to the time frame to which these indicators refer. International comparative economic indicators are easiest to obtain, as these are often regularly published by national governments and collected - and if necessary harmonized - by international institutions like the EU, the OECD and the UN. This is particularly true for very general indicators like GDP and level of unemployment. More specific indicators focusing on young adults - like the level of youth unemployment - are often already harder to obtain. The same situation exists for institutional indicators, with general information on expenditures on social benefits being relatively easy to obtain, but with more specific information on institutional arrangements - like on eligibility of young adults for social benefits - being very hard, or even impossible to obtain. The fact that this type of institutional data is so hard to obtain often leads researchers to use rather crude categorical welfare state categorizations in their comparative research. The biggest challenge in this regard is to obtain internationally comparative cultural 
indicators. Such indicators - like the level of individualization or the level of secularization - generally are not available from national government sources. One solution is to use more objective indicators as proxies for more subjectively-based cultural factors. For instance, one can use the divorce rate or the proportion of single-person households as indicators for the level of individualization of countrycontexts. Another solution is to use information from internationally comparative surveys like the ones discussed above and aggregate data to the country level. For instance, one could use information from the ESS on how much individuals value autonomy to calculate the overall level of individualization in a country, by aggregating the individual-level scores to the country level, and rank order the countries.

Unfortunately, there is another issue in finding good indicators for national-level indicators that is even more daunting. If one wants to examine whether a crossnational indicator moderates the individual-level relationship between childhood disadvantage and adult outcomes, one has to decide on the proper period to which this country-level indicator should refer. For instance, if one wants to examine whether the relationship between experiencing a parental divorce during childhood and the timing of marriage is moderated by societal norms about divorce, one probably would want these societal norms to be measured during the respondent's adolescence. In particular for older cohorts - basically all cohorts born before 1965 - such information is hard to come by. The EVS is the cross-national survey with information on values that goes back in time the farthest, with its first round of data being collected in 1981. However, Eastern European countries only started to participate in the EVS from 1990 onwards. As a result, in practice one often has to settle either for proxies - e.g. the crude divorce rate during respondents' adolescence - assuming that this proxy still sufficiently captures the concept one is interested in, or for measures obtained at a much later point in time - e.g. aggregated responses to questions on the societal acceptance of divorce obtained from the ESS in 2006 - assuming that the rank-ordering of countries in 2006 still sufficiently mirrors their rank-ordering at the time that respondents were adolescents. It is clear that both approaches have major limitations, but unless one is studying very young cohorts that have experienced adolescence after 2000, the choice boils down to either not using any cross-national indicator at all or using an imperfect one.

A fourth and final challenge is which type of analytical approach to use to test cross-national hypotheses. Even if data from international survey programmes are used, the total number of countries involved is often still relatively limited. Although multi-level analysis with individuals being nested within countries is usually viewed as the most appropriate approach (Van de Vijver et al. 2008), this approach has recently been criticized as being problematic when the number of countries being involved is smaller than 25 (Bryan and Jenkins 2016). As an alternative, metaanalysis and meta-regression could be used. The rationale for this alternative approach and an application of it to country-level analysis is presented in Chap. 6 of this book.

The CONOPP project has dealt with these four challenges in multiple ways. First, most of our studies test the Contexts of Opportunity hypothesis using data collected in the GGP, as this dataset includes a large number of countries, has large 
sample sizes, has rich information on young adults' demographic decisions, and includes information on parental education and on family structure during childhood. Some studies on young-adult demographic outcomes used data from ESS as it allowed to include a larger number of countries. However, both the number of respondents per country and the extent of information on demographic events are smaller than in the GGP. In addition, one of the studies on later-life outcomes combined information from GGP with data from SHARELIFE and the British Household Panel Study (BHPS). Second, given that parental education was the most widely available indicator in the GGP and was also included in other comparative datasets, parental education was generally used as the main indicator for childhood disadvantage. Another key indicator was whether parents had experienced a divorce before age 15. In addition, some studies used information from the ESS on parental occupation in addition to information on parental education. Third, our approach to including country-level indicators was highly pragmatic. As many of the CONOPP studies examined behaviors that occurred in the quite distant past (1970s-1990s), high-quality country-level indicators were generally not available for this time period or were available for only a subset of countries. For instance, economic and institutional indicators might be available for Western European countries, but not or constructed in incomparable ways - for Eastern European countries. The general rule used was to opt for indicators that came at least pretty close in their timing to the period in which most of the respondents experienced the relevant processes under consideration. Sometimes only specific cohorts for which country-level data was available for the relevant time period were included in studies. Finally, most of the analyses reported in CONOPP studies focused on less than 25 countries, and therefore used meta-analysis and meta-regression to test the Contexts of Opportunity hypothesis. However, if the number of countries allowed it, some studies used multi-level analysis instead. Finally, a few studies used a country fixed-effects model in which no country-level variables were included, but in which it was only examined whether the direction of country differences was in line with expectations based on our hypothesis.

\subsection{A Summary of Key Results of the CONOPP Project}

Fifteen different studies within the CONOPP project have examined cross-national differences in the relationships between childhood disadvantage, young-adult demographic decisions and later-life outcomes. Their results and their relationship to the Contexts of Opportunity hypothesis will be discussed. I will focus on two aspects. First, I discuss whether we find evidence for cross-national differences in the strength of the substantive relationships at stake. Second, I examine whether the variation in the strength of these relationships is related to differences between countries in the opportunities they offer to escape social disadvantage. Table 9.1 offers an overview of these 15 studies and provides information on their central independent and dependent variables, the number of countries involved, and their 
Table 9.1 An overview of key characteristics and results of cross-national studies conducted within the CONOPP project

\begin{tabular}{|c|c|c|c|}
\hline Study & Topic & \# & Key findings \\
\hline $\begin{array}{l}\text { Brons et al. } \\
\text { (2017) }\end{array}$ & $\begin{array}{l}\text { Parental SES \& first } \\
\text { union timing }\end{array}$ & 25 & $\begin{array}{l}\text { Significant country variation. Weaker effect } \\
\text { if cohabitation is more common, weaker } \\
\text { effect if age norms on leaving home are } \\
\text { stronger }\end{array}$ \\
\hline $\begin{array}{l}\text { Brons et al. } \\
\text { (2017) }\end{array}$ & $\begin{array}{l}\text { Parental SES \& } \\
\text { choice between } \\
\text { marriage and } \\
\text { cohabitation }\end{array}$ & 25 & $\begin{array}{l}\text { Delaying effect of parental SES stronger for } \\
\text { marriage. Weaker effects if own educational } \\
\text { level is included. Country differences result } \\
\text { from differences in educational attainment } \\
\text { between countries }\end{array}$ \\
\hline $\begin{array}{l}\text { Brons }(2020)- \\
\text { Chap. } 3\end{array}$ & $\begin{array}{l}\text { Parental education } \\
\& \text { first marriage } \\
\text { timing }\end{array}$ & 20 & $\begin{array}{l}\text { Significant country variation. No clear } \\
\text { country pattern }\end{array}$ \\
\hline $\begin{array}{l}\text { Härkönen et al. } \\
\text { (2020) }\end{array}$ & $\begin{array}{l}\text { Parental separation } \\
\& \text { choice between } \\
\text { marriage and } \\
\text { cohabitation }\end{array}$ & 15 & $\begin{array}{l}\text { Significant country variation. Weaker effect } \\
\text { on the risk of cohabitation, the more } \\
\text { common non-marital births are }\end{array}$ \\
\hline $\begin{array}{l}\text { Härkönen et al. } \\
\text { (2020) }\end{array}$ & $\begin{array}{l}\text { Parental separation } \\
\& \text { first marriage } \\
\text { timing }\end{array}$ & 15 & $\begin{array}{l}\text { Significant country variation. Weaker effect } \\
\text { if non-marital births are more common }\end{array}$ \\
\hline $\begin{array}{l}\text { Koops } \\
(2020)- \\
\text { Chap. } 4\end{array}$ & $\begin{array}{l}\text { Parental education } \\
\& \text { starting a union } \\
\text { while pregnant }\end{array}$ & 18 & $\begin{array}{l}\text { Significant country variation. Stronger } \\
\text { effect if less conservative family norms }\end{array}$ \\
\hline $\begin{array}{l}\text { Brons and } \\
\text { Härkönen } \\
\text { (2018) }\end{array}$ & $\begin{array}{l}\text { Parental education, } \\
\text { parental separation } \\
\& \text { union dissolution }\end{array}$ & 17 & $\begin{array}{l}\text { Significant country variation for parental } \\
\text { education. Weaker effect if divorce rate is } \\
\text { higher. }\end{array}$ \\
\hline $\begin{array}{l}\text { Koops et al. } \\
(2017)\end{array}$ & $\begin{array}{l}\text { Parental education } \\
\& \text { births in } \\
\text { cohabitation }\end{array}$ & 16 & $\begin{array}{l}\text { Significant country variation. Stronger } \\
\text { effects in North America and Eastern } \\
\text { Europe }\end{array}$ \\
\hline $\begin{array}{l}\text { Koops } \\
(2020)- \\
\text { Chap. } 3\end{array}$ & $\begin{array}{l}\text { Parental education } \\
\& \text { births in } \\
\text { cohabitation }\end{array}$ & 19 & $\begin{array}{l}\text { Significant country variation. Weaker effect } \\
\text { if countries more advanced in SDT. Small } \\
\text { effect of GINI }\end{array}$ \\
\hline $\begin{array}{l}\text { Koops et al. } \\
(2017)\end{array}$ & $\begin{array}{l}\text { Parental education } \\
\& \text { births while } \\
\text { single }\end{array}$ & 16 & $\begin{array}{l}\text { Significant country variation. Stronger } \\
\text { effects in North America }\end{array}$ \\
\hline $\begin{array}{l}\text { Koops } \\
(2020)- \\
\text { Chap. } 4\end{array}$ & $\begin{array}{l}\text { Parental education } \\
\& \text { births while } \\
\text { single }\end{array}$ & 18 & $\begin{array}{l}\text { Significant country variation. Stronger } \\
\text { effects if contraceptive use in countries is } \\
\text { higher }\end{array}$ \\
\hline $\begin{array}{l}\text { Mooyaart } \\
\text { (2019) - } \\
\text { Chap. } 3\end{array}$ & $\begin{array}{l}\text { Parental education } \\
\& \text { family formation } \\
\text { pathways }\end{array}$ & 4 & $\begin{array}{l}\text { SDT-like trajectories more common among } \\
\text { high SES, single parenthood among low } \\
\text { SES. Differences increase over cohorts. }\end{array}$ \\
\hline $\begin{array}{l}\text { Han }(2020)- \\
\text { Chap. } 4\end{array}$ & $\begin{array}{l}\text { Parental divorce \& } \\
\text { family formation } \\
\text { pathways }\end{array}$ & 6 & $\begin{array}{l}\text { Parental divorce increases risk of non- } \\
\text { traditional patterns in all countries, but } \\
\text { specifics depend on SDT advancement of } \\
\text { countries. }\end{array}$ \\
\hline
\end{tabular}


Table 9.1 (continued)

\begin{tabular}{|c|c|c|c|}
\hline Study & Topic & $\begin{array}{l}\text { \# } \\
\text { Countries }\end{array}$ & Key findings \\
\hline $\begin{array}{l}\text { Zoutewelle- } \\
\text { Terovan and } \\
\text { Liefbroer } \\
(2018)\end{array}$ & $\begin{array}{l}\text { Off-time life events } \\
\text { \& later-life } \\
\text { loneliness }\end{array}$ & 12 & $\begin{array}{l}\text { Non-events and delayed events lead to more } \\
\text { loneliness. Significant country variation. } \\
\text { Stronger effects in more traditional } \\
\text { countries. }\end{array}$ \\
\hline $\begin{array}{l}\text { Muller et al. } \\
(2020)\end{array}$ & $\begin{array}{l}\text { Family trajectories } \\
\& \text { later-life } \\
\text { employment and } \\
\text { earnings }\end{array}$ & 22 & $\begin{array}{l}\text { Significant country variation. Smaller } \\
\text { differences in labour market outcomes by } \\
\text { family trajectories if FLFP is more common }\end{array}$ \\
\hline
\end{tabular}

key results, ordered by dependent variable. An additional table (Table 9.2) provides an overview of studies conducted within the CONOPP project that focus on the mechanisms linking childhood disadvantage and young-adult demographic outcomes (six studies) or on methodological contributions in studying these processes (four studies).

A first finding of the studies is that childhood disadvantage mattered for all adult outcomes studied. Compared to their peers from higher SES backgrounds, young adults from lower SES backgrounds start partner relationships (both unmarried cohabitation and marriage) earlier, are more likely to opt for cohabitation as their first type of union, are more likely to have their first child within a cohabiting union or while being single, and are less likely to enter a union if they have conceived a child while being single. Young adults from lower SES backgrounds are also more likely to follow family trajectories in young adulthood that include long spells of single parenthood than their counterparts from higher SES backgrounds. At the same time, young adults from lower SES backgrounds are less likely to dissolve unions than young adults from higher SES backgrounds. But the long arm of childhood disadvantage even reaches into older adulthood, with higher levels of loneliness, lower levels of employment and lower incomes among adults from lower SES backgrounds than children from higher SES backgrounds. Whether adults had experienced parental separation during their childhood also mattered. Compared to young adults who grew up with both biological parents, young adults who had experienced a parental separation were more likely to opt for cohabitation, were more likely to postpone or forego marriage, were more likely to experience divorce themselves, and more likely to opt for family trajectories that entail less family commitment.

Do these differences matter? Not necessarily. However, early union formation, unmarried cohabitation, births outside a stable union, births in cohabitation, divorce, and family trajectories with long spells of single parenthood are factors that - in many societies - put people at increased risks of experiencing socio-economic and socio-emotional deprivation (Hobcraft and Kiernan 2001). In that respect, these studies suggest that adults from disadvantaged families are at a much higher risk of experiencing these negative life outcomes than adults from more advantaged 
Table 9.2 An overview of key characteristics and results of additional studies conducted within the CONOPP project

\begin{tabular}{|c|c|c|}
\hline Study & Topic & Key findings \\
\hline $\begin{array}{l}\text { Billari et al. } \\
\text { (2019) }\end{array}$ & $\begin{array}{l}\text { Mechanisms linking parental SES } \\
\text { and demographic events in three } \\
\text { countries }\end{array}$ & $\begin{array}{l}\text { Parental SES influences timing via } \\
\text { socialization, opportunity and agency. } \\
\text { Mechanisms generally are the same across } \\
\text { countries }\end{array}$ \\
\hline $\begin{array}{l}\text { Mooyaart and } \\
\text { Liefbroer } \\
(2016)\end{array}$ & $\begin{array}{l}\text { Cohort change in the link between } \\
\text { parental SES and first union } \\
\text { timing in the Netherlands }\end{array}$ & $\begin{array}{l}\text { Effect changes little over cohorts. Stronger } \\
\text { effect on first marriage than on first union. } \\
\text { Effect wanes with age. }\end{array}$ \\
\hline $\begin{array}{l}\text { Mooyaart } \\
\text { et al. (2019) }\end{array}$ & $\begin{array}{l}\text { Childhood disadvantage, young } \\
\text { adult trajectories and obesity in the } \\
\text { USA }\end{array}$ & $\begin{array}{l}\text { Traditional family trajectories increase risk } \\
\text { of obesity. Effect parental SES partially } \\
\text { mediated by family trajectories }\end{array}$ \\
\hline $\begin{array}{l}\text { Mooyaart } \\
(2019)- \\
\text { Chap. } 4\end{array}$ & $\begin{array}{l}\text { Childhood disadvantage, young } \\
\text { adult trajectories and earnings in } \\
\text { the USA }\end{array}$ & $\begin{array}{l}\text { Family and employment trajectories in early } \\
\text { adulthood partially mediate effect of } \\
\text { parental background factors on earning in } \\
\text { early } 30 \text { s }\end{array}$ \\
\hline $\begin{array}{l}\text { Keijer et al. } \\
(2016)\end{array}$ & $\begin{array}{l}\text { Links between parental economic } \\
\text { and cultural status and } \\
\text { adolescents' life-course } \\
\text { preferences in the Netherlands }\end{array}$ & $\begin{array}{l}\text { Stronger effects of cultural status than of } \\
\text { economic status. Effects mediated by } \\
\text { parents' preferences and children's level of } \\
\text { education }\end{array}$ \\
\hline $\begin{array}{l}\text { Keijer et al. } \\
(2018)\end{array}$ & $\begin{array}{l}\text { Role of value transmission and } \\
\text { modelling in explaining } \\
\text { adolescents' timing of life plans in } \\
\text { the Netherlands }\end{array}$ & $\begin{array}{l}\text { Both value transmission and modelling are } \\
\text { important predictors of the timing } \\
\text { expectations of adolescents. No differences } \\
\text { by gender of parent or gender of child. }\end{array}$ \\
\hline $\begin{array}{l}\text { Studer et al. } \\
\text { (2018) }\end{array}$ & $\begin{array}{l}\text { Development and illustration of } \\
\text { Competing Trajectories Analysis } \\
\text { (CTA) }\end{array}$ & $\begin{array}{l}\text { CTA facilitates comparison of life } \\
\text { trajectories whose structure is strongly } \\
\text { influenced by differences in the timing of } \\
\text { events. }\end{array}$ \\
\hline $\begin{array}{l}\text { Han et al. } \\
(2017)\end{array}$ & $\begin{array}{l}\text { Comparing sequence analysis and } \\
\text { latent class analyse to analyse } \\
\text { life-course trajectories }\end{array}$ & $\begin{array}{l}\text { Best practices for both methods are } \\
\text { discussed and results compared. Differences } \\
\text { between both methods seem to be limited }\end{array}$ \\
\hline $\begin{array}{l}\text { Han et al. } \\
(2020)\end{array}$ & $\begin{array}{l}\text { Applying Hidden Markov models } \\
\text { to model life-course processes }\end{array}$ & $\begin{array}{l}\text { Hidden Markov models can be used to } \\
\text { examine how social background factors } \\
\text { influence different phases of the transition } \\
\text { to adulthood }\end{array}$ \\
\hline $\begin{array}{l}\text { Han } \\
(2020)- \\
\text { Chap. } 5\end{array}$ & $\begin{array}{l}\text { Applying Hidden Markov models } \\
\text { to model interrelationship between } \\
\text { life-course domains }\end{array}$ & $\begin{array}{l}\text { Hidden Markov models can be used to } \\
\text { model the interrelationship between family } \\
\text { and work trajectories and how these vary by } \\
\text { social background }\end{array}$ \\
\hline
\end{tabular}

families, and that part of these differences may result from differences in their demographic choices in young adulthood.

A second finding of these studies is that the strength of the relationship between childhood disadvantage and young-adult demographic outcomes shows crossnational variation for almost all indicators that were examined. This is strong evidence that context matters. In some instances, childhood disadvantage mattered in all countries, but only the extent to which it mattered differed across countries. In other instance, childhood disadvantage mattered in some countries, but did not 
influence demographic decisions in other countries. The relationship between family trajectories and later-life outcomes also turned out to vary considerably across countries. Taken together, this strong cross-national variation in effect sizes suggests that we should be cautious in generalizing results on the consequences of childhood disadvantage found in one country context to other country contexts. Additionally, a number of studies also examined changes in the strength of the relationship between childhood disadvantage and adult outcomes more dynamically, by looking at changes within countries over time. Generally, these studies did not find evidence for change in the consequences of childhood disadvantage. Rather, withincountry differences by social background were surprisingly stable over time.

A third finding of these studies is that some evidence was obtained that the crossnational variation observed could be related to country-level economic, cultural or institutional factors. The clearest evidence, in this respect, was found for cultural factors. The relationship between parental SES and the timing of first union was weaker in countries where cohabitation is more common and where age norms concerning leaving home are weaker. The relationship between parental separation and the risk of cohabitation and between parental separation and the timing of marriage are weaker the more common non-marital births are. The relationship between parental separation and young adults' own divorce is weaker in countries where divorce is more common. The relationship between parental education and having a birth in cohabitation is weaker in countries with less conservative marriage norms. The same is true for the relationship between parental education and starting to live with a partner among those who have become pregnant while living single. The relationship between non-normative family-life events and later-life loneliness was weaker in countries with less traditional value-patterns. All of these findings seem to suggest that childhood disadvantage seems to matter less in societies that are more advanced in terms of individualisation and in terms of spread of the SDT. The evidence for economic and institutional factors is much more limited. The relationship between parental SES and the choice between marriage and cohabitation is weaker once young adults' own educational level is taken into consideration, suggesting that the educational system may sometimes buffer the relationship between childhood disadvantage and adult outcomes. The relationship between women's family trajectories and later-life economic outcomes is weaker in countries where the female labour-force participation rate is higher, suggesting that institutional contexts where female labour force participation in more accepted - and potentially also better supported - reduce inequalities based on different family-life trajectories. 


\subsection{Contexts of Opportunity? An Assessment of Results and Future Outlook}

The findings from the CONOPP project show that childhood background is strongly related to a large variety of adult outcomes, and this is true in almost all country contexts and within countries over time. This is observed both for indicators of parental socio-economic status and for indicators of household structure during childhood. Demographic choices in young adulthood are thus clearly stratified, suggesting that individual choice in young adulthood very often is unequal choice. Although many CONOPP studies focussed on examining the extent of stratification of demographic choices across countries rather than on explaining this stratification, several of our studies did offer clues to why choice is unequal. An important avenue of stratification is the intergenerational transmission of educational opportunities. Children from disadvantaged parents are less likely to achieve high levels of education, and this low level of own achieved education increases the risk of disadvantage in adult life. But intergenerational transmission of educational opportunities is far from the full story. Children from disadvantaged and advantaged backgrounds also differ in their values, attitudes and life-course preferences as a result of socialization processes. Parents were found to transmit their own behaviors and preferences both deliberately and unintendedly. Furthermore, children from advantaged backgrounds were found to be better able to realize their preferences than children from disadvantaged background, suggesting that life-course agency is unequally distributed. Thus, several mechanisms lead to unequal choice in demographic behaviors and later-life outcomes. Given that these unequal choices and unequal outcomes can be traced back to inequality in childhood circumstances, they show that childhood disadvantage has pervasive consequences for adult life, even in societies that view themselves as being meritocratic and achievement-oriented.

In almost all instances, our studies found that the strength of the relationships varied by country context. This is a clear reminder that contexts matter for understanding demographic processes. This is something that researchers are keenly aware when studying levels of demographic indicators, but our studies show that the same is true for the strength of the relationship between demographic indicators and potential determinants. This is an area of demographic research where a lot of progress still can be achieved.

The variation in the strength of the relationship between childhood disadvantage and young-adult demographic outcomes often seemed to be related to country differences in cultural factors, like the level of individualisation of countries or the extent to which behaviors like unmarried cohabitation and divorce had diffused across countries. Probably, the importance of culture is the result of several, potentially interrelated processes. On the one hand, children who have experienced events that are often stigmatized, like a parental divorce or having been born outside of wedlock, may experience less stigma in individualized societies, and this may increase the likelihood that their behaviors as young adults may align with those of young adults who have not experienced these stigmatizing events. On the other hand, in individualized contexts, young adults from advantaged backgrounds - who 
are more likely to be raised to make autonomous life choices - may be more inclined to opt for behaviors that used to be viewed as non-normative, such as unmarried cohabitation and having children outside marriage, as long as these behaviors are viewed as fitting a more individualized, less committal, lifestyle. As a result, the behaviors of those from disadvantaged and those of advantaged backgrounds may differ less from each other, the more individualized the country context is. These kinds of explanations are largely in line with what one would expect based on ideas from Second Demographic Transition theory.

We found only limited indications that cross-national differences in the relationship between childhood disadvantage and young-adult demographic choices were related to country-level economic and institutional factors. I am not convinced, though, that this implies that these kinds of factors are unimportant. A number of arguments to underscore this point of view could be put forward. First, the fact that it was hard to construct high-quality comparative indicators for relevant economic and institutional factors may have played a role. As mentioned earlier, it is particularly hard to find indicators that refer to the relevant periods in people's lives. Given that we used retrospective data, country-level indicators should often have been targeted to periods in the second half of the previous century to get a good fit, and for many countries these indicators were not available for these time-periods. In a number of studies, we restricted our analyses to relatively recent cohorts, but even in these instances, it was hard to find high-quality country-level indicators. A second reason is that economic, cultural and institutional country-level indicators are often highly correlated, making it hard to disentangle their effects. This problem is exacerbated by the fact that the number of countries included in the analyses is relatively small, making it empirically difficult to simultaneously estimate moderating effects of multiple country-level factors. However, this is not just an empirical problem. It is not by coincidence that - at the country level - economic prosperity, individualized value systems and relatively strong welfare state arrangement often are interlinked, whereas the same is true for the combination of economic waywardness, value systems emphasizing traditional family values and relatively weak welfare state arrangements. Although better measurements of these aspects certainly are needed, they will not be sufficient to convincingly disentangle these factors, and it could always be argued that a slightly different - but unfortunately not available indicator would perform better. I am convinced that data and methods alone will not suffice, but that it is theoretical arguments about why a particular country-level aspect - or combination of country-level aspects - is important, in combination with empirical results underscoring these arguments, that decide on whether our explanations are more or less convincing. Thus, in the end, it is a critical debate about the most plausible explanations - backed up by data and models - that matters to advance our understanding of cross-national variation in the relationships between childhood disadvantage and adult outcomes. In my assessment, this implies that the verdict on the Contexts of Opportunity hypothesis is still open. Adults from disadvantaged backgrounds fare better in countries with better opportunities to counteract the potential negative consequences of childhood disadvantage. Our results suggest quite strongly that this is true for cultural opportunities to make 
non-normative choices, but more evidence is still needed to underscore the claim that the same is true for economic and welfare state opportunities.

It was not possible to delve into all aspects of the relationship between childhood disadvantage and adult outcomes as deeply as I would have wanted. A number of issues definitely need more attention in future research. First, the role of gender could be examined more thoroughly. Are men and women equally impacted by childhood disadvantage? Several of our studies suggest that this is quite true for young-adult demographic choices, but we did not systematically examine this for all aspects. Second, more attention could be given to mediating factors in crossnational research. For instance, how much of the total effect of childhood disadvantage on adult outcomes is mediated by young adults' own educational attainment and how strongly does this mediation vary across countries? The role of parents' socialization practices may also be relevant in this regard. Part of the effect may be mediated by the extent to which parents emphasize control and autonomy in their socialization practices and the strength of this link may also differ across countries. Anyway, a better grasp on the extent to which the processes linking childhood disadvantage and adult outcomes vary across countries would be welcome. Third, more attention could be given to cohort changes within countries in the relationship between childhood disadvantage and adult outcomes. Most of our studies did not address this issue, but the few that did, did not show strong shifts across cohorts. One could argue that this underscores the thesis that childhood disadvantage remains an important dimension of inequality in modern societies. However, it does not sit easily with our arguments about cross-national differences. These arguments are often based on the assertion that countries are at different stages of developmental processes, like being in different stages of the Second Demographic Transition. If this is a viable explanation for these cross-national differences, it also implies that countries over time will move from one stage to another and that the same kind of patterns that are observed cross-nationally should be observed within countries over time. The fact that we - as yet - found little evidence to underscore this explanation at least sheds doubts on the generalizability of the arguments across time and place. Empirically, it would be interesting to analyse the role of the macro-context both across countries and across cohorts in one statistical model. Although this is possible in principle, it is quite daunting in practice. Estimation of such a cross-classified model is not easy, and it might be very hard to find macro-level indicators that both vary across countries and within countries at the same time. Still, it would be an important avenue for future research.

The CONOPP project clearly shows the long arm of childhood disadvantage. Children from low SES backgrounds and those who grew up experiencing parental separation on average are more likely to make demographic choices during young adulthood with potentially negative consequences for their economic or socioemotional well-being and these effects can persist into later life. This does not imply that this is true for everyone. Many children who are classified as 'disadvantaged' do very well as adults and many who are classified as 'advantaged' do not. But on average, there is clear difference between both groups. Given that children cannot help the situation they encounter during childhood, this should be a concern to 
politicians and policy makers. It would be important to shape the opportunity structures facing children and young adults who have grown up in disadvantaged situations in such a way that their life chances become more equal. Clearly, this project does not provide a recipe how this should be done. However, the Contexts of Opportunity hypothesis suggests that it is about making resources available to equalize life chances. Education is a powerful tool in this regard, but if success in the educational system itself is highly stratified this will only have limited impact. Therefore, it is important to weaken the reproduction of inequality that still is going on, often unconsciously, in the educational system. Furthermore, it is important to strengthen the resources available to families of disadvantage, in order to reduce the consequences of their own limited access to resources. Improving the economic situation of those who are disadvantaged is one clear example. However, strengthening resources is not just about strengthening economic resources available to children of disadvantage, but also about strengthening their cultural and psychological resources. It is about making adolescents and young adults resilient in dealing with misfortune and negative life events. Such a multifaceted approach may - over time succeed in decreasing these inequalities and weaken the links between childhood disadvantage and poor adult outcomes.

Acknowledgements The research leading to these results has received funding from the European Research Council under the European Union's Seventh Framework Programme (FP/2007-2013)/ ERC Grant Agreement n. 324178.

\section{References}

Amato, P.R., N.S. Landale, T.C. Havasevich-Brooks, A. Booth, D.J. Eggebeen, R. Schoen, and S.M. McHale. 2008. Precursors of young women's family formation pathways. Journal of Marriage and Family 70 (5): 1271-1286.

Billari, F.C., and A.C. Liefbroer. 2010. Towards a new pattern of transition to adulthood? Advances in Life Course Research 15 (2-3): 59-75.

Billari, F.C., N. Hiekel, and A.C. Liefbroer. 2019. The social stratification of choice in the transition to adulthood. European Sociological Review 35 (5): 599-615.

Blossfeld, H.-P., E. Klijzing, M. Mills, and K. Kurz, eds. 2005. Globalization, uncertainty and youth in society. London: Routledge.

Börsch-Supan, A., M. Brandt, C. Hunkler, T. Kneip, J. Korbmacher, F. Malter, B. Schaan, S. Stuck, and S. Zuber. 2013. Data resource profile: The Survey of Health, Ageing and Retirement in Europe (SHARE). International Journal of Epidemiology 42 (4): 992-1001.

Brons, M.D. 2020. Family background and union formation and dissolution processes. A crossnational perspective ( $\mathrm{PhD}$ thesis). Amsterdam: Vrije Universiteit.

Brons, M.D., and J. Härkönen. 2018. Parental education and family dissolution: A cross-national and cohort comparison. Journal of Marriage and Family 80 (2): 426-443.

Brons, M.D., A.C. Liefbroer, and H.B.G. Ganzeboom. 2017. Parental socio-economic status and first union formation: Can European variation be explained by the Second Demographic Transition theory? European Sociological Review 33 (6): 809-822.

Bryan, M.L., and S.P. Jenkins. 2016. Multilevel modelling of country effects: A cautionary tale. European Sociological Review 32 (1): 3-22. 
Dobbelaere, K. 1981. Trend Report. Secularization: A multi-dimensional concept. Current Sociology 29 (2): 3-153.

Esping-Andersen, G. 1990. The three worlds of welfare capitalism. Oxford: Polity Press.

. 1999. Social foundations of postindustrial economies. Oxford: Oxford University Press.

Feldhaus, M., and V. Heintz-Martin. 2015. Long-term effects of parental separation: Impacts of parental separation during childhood on the timing and the risk of cohabitation, marriage, and divorce in adulthood. Advances in Life Course Research 26: 22-31.

Frick, J.R., S.P. Jenkings, D.R. Lillard, O. Lipps, and M. Wooden. 2007. The Cross-National Equivalent File (CNEF) and its member country Household Panel Studies. Schmollers Jahrbuch: Zeitschrift für Wirtschafts- und Sozialwissenschaften 127 (4): 627-654.

Gauthier, A.H., S.L.F. Cabaço, and T. Emery. 2018. Generations and Gender Survey study profile. Longitudinal and Life Course Studies 9 (4): 456-465.

Gelissen, J., and L. Halman. 2018. European values survey. In The Blackwell Encyclopedia of Sociology, 1-4. Malden: Wiley.

Gorski, P.S., and A. Altinordu. 2008. After secularization? Annual Review of Sociology 34: 55-85.

Han, S.Y. 2020. Latent state models for classifying and explaining processes in young adults' life courses (PhD thesis). Amsterdam: Vrije Universiteit.

Han, S.Y., A.C. Liefbroer, and C.H. Elzinga. 2017. Comparing methods of classifying life courses: Sequence analysis and latent class analysis. Longitudinal and Life Course Studies 8 (4): 319-341.

-2020. Mechanisms of family formation: An application of hidden Markov models to a life course process. Advances in Life Course Research 43: 100265.

Härkönen, J., and J. Dronkers. 2006. Stability and change in the educational gradient of divorce. A comparison of seventeen countries. European Sociological Review 22 (5): 501-517.

Härkönen, J., M.D. Brons, and J. Dronkers. 2020. Family forerunners? Parental separation and partnership formation in 16 countries. Journal of Marriage and Family.

Hobcraft, J., and K. Kiernan. 2001. Childhood poverty, early motherhood and adult social exclusion. British Journal of Sociology 52: 495-517.

Kalmijn, M. 2007. Explaining cross-national differences in marriage, cohabitation, and divorce in Europe, 1990-2000. Population Studies 61 (3): 243-263.

Keijer, M.G., I. Nagel, and A.C. Liefbroer. 2016. Effects of parental cultural and economic status on adolescents' life course preferences. European Sociological Review 32 (5): 607-618.

Keijer, M.G., A.C. Liefbroer, and I. Nagel. 2018. Adolescents' expectations about the timing of family life events: Unraveling the role of value transmission and modeling. Journal of Family Issues 39 (15): 3755-3777.

Koops, J.C. 2020). Understanding nonmarital childbearing in Europe and North-America. The role of socio-economic background and ethnicity in different societal contexts ( $\mathrm{PhD}$ thesis). University of Groningen, Groningen.

Koops, J.C., A.C. Liefbroer, and A.H. Gauthier. 2017. The influence of parental educational attainment on the partnership context at first birth in 16 Western societies. European Journal of Population 33 (4): 533-557.

Lesthaeghe, R. 2014. The second demographic transition: A concise overview of its development. Proceedings of the National Academy of Sciences 111 (51): 18112-18115.

Lesthaeghe, R., and D.J. Van de Kaa. 1986. Twee demografische transities? [Two demographic transitions?]. In Bevolking: groei en krimp, ed. D.J. Van de Kaa and R. Lesthaeghe, 9-24. Deventer: Van Loghum Slaterus.

Mooyaart, J.E. 2019. Linkages between family background, family formation and disadvantage in young adulthood ( $\mathrm{PhD}$ thesis). University of Groningen, Groningen.

Mooyaart, J.E., and A.C. Liefbroer. 2016. The influence of parental education on timing and type of union formation: Changes over the life course and over time in the Netherlands. Demography 53 (4): 885-919.

Mooyaart, J.E., A.C. Liefbroer, and F.C. Billari. 2019. Becoming obese in young adulthood: The role of career-family pathways in the transition to adulthood for men and women. BMC Public Health 19 (1): 1511. 
Muller, J.S., N. Hiekel, and A.C. Liefbroer. 2020. The long-term costs of family trajectories: Women's later-life employment and earnings across Europe. Demography 57 (3): 1007-1034.

Perelli-Harris, B., and T.P. Gerber. 2011. Nonmarital childbearing in Russia: Second demographic transition or pattern of disadvantage? Demography 48 (1): 317-342.

Perelli-Harris, B., and M. Lyons-Amos. 2016. Partnership patterns in the United States and across Europe: The role of education and country context. Social Forces 95 (1): 251-281.

Perelli-Harris, B., W. Sigle-Rushton, M. Kreyenfeld, T. Lappegård, R. Keizer, and C. Berghammer. 2010. The educational gradient of childbearing within cohabitation in Europe. Population and Development Review 36 (4): 775-801.

Ruggles, S. 2014. Big microdata for population research. Demography 51 (1): 287-297.

Schnaudt, C., M. Weinhardt, R. Fitzgerald, and S. Liebig. 2014. The European Social Survey: Contents, design, and research potential. Journal of Contextual Economics - Schmollers Jahrbuch 134 (4): 487-506.

Sobotka, T. 2008. The diverse faces of the Second Demographic Transition in Europe. Demographic Research 19 (8): 171-224.

Studer, M., A.C. Liefbroer, and J.E. Mooyaart. 2018. Understanding trends in family formation trajectories: An application of Competing Trajectories Analysis (CTA). Advances in Life Course Research 36: 1-12.

Thévenon, O., and A.H. Gauthier. 2011. Family policies in developed countries: A 'fertilitybooster' with side-effects. Community, Work \& Family 14 (2): 197-216.

Van Bavel, J. 2010. Choice of study discipline and the postponement of motherhood in Europe: The impact of expected earnings, gender composition, and family attitudes. Demography 47 (2): 439-458.

Van de Kaa, D.J. 1987. Europe's second demographic transition. Population Bulletin 42 (1). 1996. Anchored narratives: The story and findings of half a century of research into the determinants of fertility. Population Studies 50 (3): 389-432.

Van de Vijver, F.J.R., D.A. Van Hemert, and Y.H. Poortinga. 2008. Multilevel analysis of individuals and cultures. New York: Lawrence Erlbaum.

Wagner, M., and B. Weiß. 2006. On the variation of divorce risks in Europe: Findings from a metaanalysis of European longitudinal studies. European Sociological Review 22 (5): 483-500.

Wolf, C., S.L. Schneider, D. Behr, and D. Joye. 2016. Harmonizing survey questions between cultures and over time. In The SAGE handbook of survey methodology, ed. C. Wolf, D. Joye, T.W. Smith, and Y.-c. Fu, 502-524. London: Sage.

Wolfinger, N.H. 2000. Beyond the intergenerational transmission of divorce: Do people replicate the patterns of marital instability they grew up with? Journal of Family Issues 21 (8): 1061-1086.

Zoutewelle-Terovan, M., and A.C. Liefbroer. 2018. Swimming against the stream: Non-normative family transitions and loneliness in later life across 12 nations. The Gerontologist 58 (6): 1096-1108.

Open Access This chapter is licensed under the terms of the Creative Commons Attribution 4.0 International License (http://creativecommons.org/licenses/by/4.0/), which permits use, sharing, adaptation, distribution and reproduction in any medium or format, as long as you give appropriate credit to the original author(s) and the source, provide a link to the Creative Commons license and indicate if changes were made.

The images or other third party material in this chapter are included in the chapter's Creative Commons license, unless indicated otherwise in a credit line to the material. If material is not included in the chapter's Creative Commons license and your intended use is not permitted by statutory regulation or exceeds the permitted use, you will need to obtain permission directly from the copyright holder.

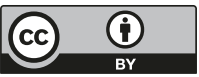

